\title{
TYPOLOGY OF URALIC LANGUAGES: CURRENT VIEWS AND NEW PERSPECTIVES. INTRODUCTION TO THE SPECIAL ISSUE OF ESUKA - JEFUL
}

\author{
Gerson Klumpp ${ }^{1}$, Lidia Federica Mazzitelli² ${ }^{2}$ and \\ Fedor Rozhanskiy ${ }^{1,3}$ \\ ${ }^{1}$ University of Tartu, ${ }^{2}$ University of Cologne, and \\ ${ }^{3}$ Institute for Linguistic Studies RAS
}

\begin{abstract}
In our introduction to the volume, we address the history and current developments in Uralic studies, with particular attention to the evolution of grammar-writing since the very first Uralic grammars until today, and summarize some of the most interesting Uralic phenomena from a typological point of view. In Section 2 we show that, even though Uralic studies can boast a remarkable number of linguistic studies and a rich production of descriptive grammars, the published grammars often lack in comparability (as they use different terms to describe the same phenomena), international reach and they often are not typologically informed. Therefore, we advocate for a stronger cooperation between typology and Uralic studies. In Section 3 we present the papers included in this special edition of ESUKA, a selection of typologically-informed, data-driven and terminologically consistent studies of different phenomena in a number of Uralic languages. Finally, in Section 4 we present a short overview of some typologically relevant features in Uralic languages.
\end{abstract}

Keywords: Uralic studies, typological features, grammar-writing

DOI: https://doi.org/10.12697/jeful.2018.9.1.01

\section{Introductory note}

This volume is based on papers read at the workshop "Typology of Uralic Languages: Towards Better Comparability" during the 49th Annual Meeting of the Societas Linguistica Europaea (Naples, 31 August - 2 September 2016). The aim of the workshop was to bring together researchers working on Uralic languages within the contemporary typological framework, in order to foster and prompt discussion on how Uralic linguistics can profit from typology, and vice versa. 
In the following, we first present an overview of what we consider to be the most urgent problems to be solved in contemporary Uralic linguistics. In Section 3 we sketch an overview of the papers presented in this volume. Finally, in Section 4 we offer a typological portrait of 30 Uralic languages based on a comparative selection of phonetic, phonological and morphosyntactic features.

\section{Two centuries of Uralic linguistics: old problems and new perspectives}

The original idea to organise such a workshop derived from the observation of what we consider being the major flaw of contemporary Uralic studies, namely, the lack of up-to-date synchronic grammars based on modern linguistic theory, accessible and understandable not only to Uralists but also to general linguists. As a consequence, Uralic languages are often under- and even misrepresented in typological works. A good example is the World Atlas of Language Structures (WALS, Dryer and Haspelmath 2013), a reference tool used by typologists all over the world. In WALS, most of the Uralic languages are represented by crucially outdated grammars, mainly due to the lack of available up-to-date sources (cf. Ariste 1968 - in fact 1948 - for Votic; Bubrix 1949, Lytkin 1966 for Komi-Zyryan; Ristinen 1960, Kovedjaeva 1966 for Mari; Sjögren 1861, Laanest 1982 for Livonian).

Not only are many of the grammars currently available for Uralic languages outdated, they are also written according to an old-fashioned style that does not reflect the latest findings in linguistic theory. The reason for such a standstill in the grammar-writing tradition of Uralic languages can be found in its history. An intensive investigation of Uralic languages (especially the Finno-Ugric branch) started already in the middle of the 19th century with the works by eminent scholars such as Matthias Castrén, Elias Lönnrot and Antal Reguly. However, what should have been an advantage, namely, its long-lasting and prolific tradition of description and analysis, has actually hindered the development of a modern grammar-writing practice. In the 19th century, the dominating research paradigm was historical linguistics, which became and remained the basis of Uralic studies for many decades. The 19th century Finno-Ugrists were highly proficient, and their authority developed into something approaching a cult for subsequent generations of scholars. Quoting the previous research became more important than 
collecting new data and proposing new interpretations. Consequently, the application of new linguistic concepts and approaches slowed down considerably.

The grammar-writing standards in Uralic studies also did not improve when, in the 20th century, native speakers of Uralic languages started writing grammars themselves, following the establishment of intellectual elites in their respective national communities. Many such grammars were only understandable to the speakers of the described language or related languages, but not to a public with no knowledge of any Uralic language. Also, as they often aimed to produce practical tools for the language communities, authors combined the principles of normative, descriptive and educational grammars.

In particular, a number of flaws can be found in what we can define as the "typical standard" of the 20th century Uralic grammars. First, the grammar provides much diachronic data, mixed with information on the synchronic state of the language, with no clear-cut distinction between diachrony and synchrony. Phonetics and morphology play a central role in the description, while syntax is described either superficially or, more often, is entirely missing. The phonetic-phonological part of the description is usually limited to addressing the basic principles of the general phonology, describing the pronunciation of particular sounds and discussing some orthographical problems. As a result, there are no clear-cut boundaries between phonology, phonetics and orthography. For languages that have a literary tradition, examples are often taken from the works of famous writers and it is often not clear which variety they represent. Finally, the descriptions are based on language-specific categories. The question of consistency with other descriptions is ignored, so the degree of comparability between different Uralic grammars is very low. Compare for example the use of the term "accusative" for the case of the direct object in the Finnish tradition with the Estonian tradition of using the terms "nominative" and "genitive" for the same function. Another example is the class of ideophones: in Mari, they are called "imitative words", while in Komi they are often mentioned among the adverbs and interjections (Komi jazyk 1998: 139, 278). Furthermore, many descriptions suffer from excessive borrowing of description patterns from major languages (mainly Russian).

A further obstacle to the integration of Uralic studies into the broader typological field is the language of publication. The traditional language of Finno-Ugric research was German. American linguists of the 20th century had almost no interest and/or access to the Uralic languages, so 
there were very few descriptions in English. Consider, for example, the list of publications on the Votic language. Votic has been rather lucky in this respect because the grammar by Ariste (1948) was translated into English in 1968 and thus the language data became available for typologists (in WALS, the Finnic languages are represented mostly by Estonian, Finnish, and Votic $^{1}$ ). Still, among more than 400 papers on Votic published before the 21 st century ${ }^{2}$, the distribution by the language of publication is the following: 38\% Estonian, 24\% Finnish, 21\% German, 8\% Russian, 5\% English, 3\% Hungarian, and 1\% other. Obviously, many of these works are not accessible to a wide circle of contemporary linguists. For the majority of Uralic languages, the situation is even worse.

Apart from tradition, an important factor that diminishes the number of publications in English is the necessity to promote the interests of the language communities. If there are not enough grammars and dictionaries, a language cannot be properly taught, so it disappears more quickly. Many members of Uralic language communities do not know English. For this reason, teaching materials should be published either in their native language or in a language of wider communication known by the speakers. For many Uralic communities this means Russian. Publishing parallel grammars in English is time- and laborconsuming, and in most cases it is not done.

The problems as described above - conservatism, lack of integration into contemporary linguistics and up-to-date synchronic grammars, weak intragenetic typological descriptions - have been well realised by many contemporary scholars. In recent years, new approaches have been employed, so that one can speak of the first steps in the "renovation" of Uralic studies. Recent grammars published in English (e.g. Siegl 2013, Nikolaeva 2014, Wilbur 2015, and the shorter descriptions Winkler 2001, Nikolaeva 1999) present Uralic material within the contemporary functional-typological framework. Two typologically oriented volumes were published in the last few years: "Negation in Uralic languages" (Miestamo, Tamm and Wagner-Nagy 2015) and "Uralic Essive and the Expression of Impermanent State" (De Groot 2017). Both are based on a unified questionnaire that allows an easy comparison of the data from

1 More precisely: in WALS, there are 155 entries with Finnish data, 60 with Estonian, 17 with Votic, 6 with Karelian, 5 with Livonian, and 1 with Ingrian and Veps (Dryer and Haspelmath 2013).

2 The calculations were made from the Votic bibliography as listed in (Markus and Rožanskiy 2017). 
different Uralic languages. A further typological project, "The Oxford Guide to the Uralic languages", initiated and supervised by M. BakróNagy, J. Laakso, and E. Skribnik, is currently in progress.

In our view, a number of desiderata should be implemented in the further development of Uralic studies ${ }^{3}$. First of all, new descriptions of Uralic varieties should be compiled, according to the desiderata that have been exposed above: such descriptions should take into account the findings of typological research and should be based on up-to-date data, collected and documented according to the latest standards and techniques (cf. Himmelmann 2006). Furthermore, a clear distinction should be made between reference grammars and materials conceived for the language communities (teaching materials, normative grammars). The intragenetic typology of the Uralic languages should be developed, paying special attention to the issue of the comparability of linguistic data. Finally, the number of publications in English should increase, in order to make Uralic data available to a wider circle of linguists.

\section{This volume: an overview}

As mentioned before, we strongly advocate a renewal in the discipline of Uralic studies that would include more publications in English, the use of a functional-typological framework in descriptions and a consequent increase in the extra- and intragenetic comparability of linguistic data. The papers collected in this volume aim to contribute to this renewal, offering new perspectives on "old questions", based on experimental data and inspired by the contemporary typological research.

The first paper of the volume, by Matti Miestamo, offers a reflection on the main issues tackled by our workshop, namely, the relationship between typology and descriptive linguistics as well as the current state of description in Uralic studies.

Ksenia Shagal presents a typological study of participles in the Uralic languages. Her findings show that Uralic participial systems, though showing some common properties, display a high degree of variation. In particular, Uralic languages diverge insofar as the orientation of the participles is concerned, with some languages allowing contex-

3 We do not mention here the highly important activities on maintenance and revitalization of minor languages, since this is a large separate field that requires a different discussion. 
tually oriented participles (which relativise all kinds of participants) while others have only inherently oriented participles (which allow the relativization of only one kind of participant). Shagal's analysis also shows that the distribution of participial types within the Uralic family is clearly areally determined.

Nikita Muravyev's paper analyses the morphosyntax of expressions conveying the meaning of "simultaneity" in three Finno-Ugric languages: Izhma Komi, Northern Khanty and Moksha. His analysis, based on fieldwork data, focuses on the semantic and discoursepragmatic constraints that govern converbs in the three examined languages. Muravyev shows that variation in the use of converbs is determined not only by the aspectual properties of the matrix and dependent predicates, but also by their pragmatic properties (as the givenness of the dependent predicate).

Timofey Arkhangelskiy and Maria Usacheva provide an account of Beserman Udmurt case-compounding (the attachment of multiple case markers to a noun stem) based on new experimental data. The authors start by reviewing the existing typologies of case-compounding and then proceed to examine the morphosyntactic and pragmatic properties of the analysed phenomenon in Beserman and literary Udmurt. They also illustrate the experimental methods they used in the field to get naturalistic (un-elicited) occurrences of case-compounding, a relatively rare phenomenon in Beserman. The acquisition of a good number of instances of case-compounding in a (semi)naturalistic setting has proved crucial to understanding the semantic and pragmatic factors that influence their realization.

Polina Pleshak presents a functional study of adnominal possessive constructions in Moksha, Erzya, Meadow Mari, Hill Mari, Izhma Komi and Udmurt. Her data mostly come from her own fieldwork, and reflect the contemporary situation in the examined languages. Pleshak analyses the different constraints that regulate the use of adnominal possessives in the various constructions allowed in these languages; her results confirm previous typological claims on the relevance of semantic factors such as semantic relations, animacy and alienability for the selection of the possessive construction.

Hannah Wegener investigates the phenomenon of differential object marking in two under-documented dialects of Selkup - Central and Southern Selkup - where the direct object can be marked with either the accusative or nominative case. Her analysis shows that direct object marking in these dialects is mostly determined by morphosyntactic factors and is distributed on the nominal vs pronominal divide, with 
pronouns consistently taking accusative marking, and only nouns being subjected to the accusative/nominative alternation. Though Wegener calls for further analyses on a larger corpus of occurrences, her results highlight TAM (tense/aspect/mood) constraints (namely, imperative mood) and information structure as the factors that most influence the case choice in the two analysed dialects of Selkup.

Karl Pajusalu, Kristel Uiboaed, Péter Pomozi, Endre Németh and Tibor Fehér present an attempt to compile a phonological typology of the Uralic languages, based on the quantitative analysis of 33 prosodic and phonological features in at least two languages of all the main branches of the Uralic family. Their results correspond to the traditional groupings of Uralic languages (though with some disturbances probably due to areal factors, as in the case of Hungarian) and show an eastern/ western divide in the Uralic family.

Natalia Kuznetsova deals with the concept of "mora" in Estonian, providing a detailed and exhaustive overview of the existing approaches to describing mora in the generative and structuralist frameworks. She also offers an application of the notion of mora to the study of Estonian foot stress that can help predict morphophonological phenomena such as declension shifts in this language.

\section{A typological overview of the Uralic languages: unity and diversity}

In this section, we present four tables that show how significant the diversity in the Uralic languages is, in spite of their relatively small numbers, and offer a typological portrait of most Uralic languages. Our analysis is based on 25 phonetic and grammatical features, selected according to the following requirements:

1. A feature should not be trivial (i.e. it must have more than one value for the tested languages).

2. It is possible to define the value of the feature for the tested languages. That is, we did not include features that are crucially dependent on a particular grammatical description, i.e. that receive discording interpretations in different grammars.

Our list of features is undoubtedly rather fragmentary; its main aim, however, is to show how diverse this language family is rather than to present a comprehensive typological portrait of every language. 
The list of languages that we tested is slightly shorter than we would have desired; as mentioned above, not all Uralic languages have a detailed description of sufficient quality to allow us to get enough data on all the tested features. Altogether, we analysed 30 Uralic varieties, some of which are unambiguously considered languages, while others have been considered dialects for many years and now have a disputed status. The tables are based on data from published grammars; in doubtful cases, we also double-checked with language experts (see Acknowledgments). In the case of languages with literary traditions, we tried to avoid colloquial or bookish varieties.

The tested features are divided into four groups: phonetics and phonology $(\mathrm{P})$; nominal morphology $(\mathrm{N})$; verbal morphology $(\mathrm{V})$; and syntax (S). The first three groups have a similar number of features; it has been more difficult to test syntactic features, mainly because syntactic descriptions (as mentioned above) are scarce in the grammars we consulted. The features and their values are listed and commented on below. The mark for every value is indicated in square brackets. The sign " $\mathrm{D}$ " in the tables means that this value varies greatly depending on a particular dialect. In several cases when a language is in a transitional state, i.e. shifting from one characteristic to another, we used the symbol ">" to indicate the direction of the shift.

\section{Features and values}

\section{P1. Length-based opposition of vowels}

Values: Vowels do not have length contrast [-]

Vowels have a binary contrast: short vs long vowels [2]

Vowels have a ternary contrast: short vs long vs extra-long vowels [3]

Feature P1 concerns only the phonological contrast and does not consider the phonetic variation in vowel length. For Estonian, we postulate the ternary contrast, though it is not a purely segmental feature.

P2. Opposition of voiced and voiceless plosive consonants

Values: No phonological contrast $[-]$

The contrast exists only for a specific pair of consonants [+/-]

This phonological contrast exists $[+]$ 
Those cases where the difference between voiceless and voiced or half-voiced plosives is only an additional phonetic feature, but not a phonological contrast (as, for instance, in Ingrian), are marked with [-].

\section{P3. A series of palatal or palatalised consonants in the phonological system}

Values: No series of palatalised/palatal consonants [-]

A series palatal/palatalised is only partially formed [+/-]

A series of palatalised/palatal consonants exists $[+]$

Palatalisation is a phonological feature applicable for most consonants irrespective to the place of articulation [++]

All Uralic languages have at least three series of consonants distinguished by the place of articulation: there are labial/bilabial, dental/ alveolar and velar/uvular/pharyngeal consonants. In some Uralic languages, palatal consonants or palatalised dental/alveolar consonants form one more series. For some Uralic languages, there are unambiguous criteria distinguishing palatal and palatalised consonants; thus we do not consider this difference to be significant to the current feature. In some Uralic languages (e.g. Nenets or Kamas), palatalization has spread to the whole consonantal system.

\section{P4. Geminates}

Values: Geminates are absent or appear episodically [0]

Geminates are widespread [1]

Short and long geminates make a phonological contrast [2]

The first value distinguishes languages where the geminates are not an essential part of the phonological system. In such languages, if geminates exist, then they result mostly from assimilation. The second value marks the languages where the contrast between weak (single) and strong (geminated) consonants is phonologically significant. The third value applies to languages that have a contrast between short and full geminates (e.g. Ingrian).

\section{P5. Stress type}

Values: Stress is distinctive and has a fixed position [F]

Stress is distinctive and has a variable position [V]

Stress is not distinctive [N]

This system of stress types has been described by Rozhanskiy (2013). In many cases, the choice of the value for a particular language can be controversial because there are no good prosodic descriptions 
for most Uralic languages and the information given in grammars is often contradictory. Additionally, some languages do not represent a pure type but belong rather to a mixed type, which we mark as $F(V)$, $\mathrm{N}(\mathrm{F})$, or $\mathrm{V}(\mathrm{N})$, meaning that the language also has some features of the type indicated in parenthesis.

\section{P6. Vowel harmony}

Values: Consequent $[+]$

With many exceptions $[+/-]$

Episodic, or some other phenomena that can be considered as vowel harmony in a wider sense do exist $[-/+]$

Absent [-]

Exceptions appear when there are many formatives that do not comply with the main rule of vowel harmony in a particular language (e.g. in Votic, see Lauerma 1993). In most Uralic languages, the vowel harmony is palatal, i.e. it is based on the opposition of front and back vowels. However, languages as Meadow Mari, Hungarian and Kamas have a different harmonic system where the labial vowels form a special group. In these languages, the vowel harmony is mixed palatal-labial, and we put an additional mark (L) for such languages.

\section{P7. Consonant gradation}

Values: Exists [+]

There are only traces of it: remnants or innovations $[-/+]$

Does not exist [-]

By consonant gradation we mean a system of regular consonant alternations in a word (first of all, within a stem) that opposes a "weak" and "strong" grade of consonants.

Table 1. Phonetic and phonological features of Uralic languages

\begin{tabular}{|c|c|c|c|c|c|c|c|}
\hline Finnic & $P 1$ & $P 2$ & $P 3$ & $P 4$ & $P 5$ & P6 & $P 7$ \\
\hline Finnish & 2 & $+/-$ & $-\mathrm{D}$ & 1 & $\mathrm{~F}$ & + & + \\
\hline Karelian & 2 & $+\mathrm{D}$ & $+\mathrm{D}$ & 1 & $F$ & $+\mathrm{D}$ & + \\
\hline Veps & $-\mathrm{D}$ & + & + & $1>0$ & $\mathrm{~F}$ & $-1+$ & - \\
\hline Ingrian & 2 & $-\mathrm{D}$ & - & 2 & $F$ & + & + \\
\hline Estonian & 3 & - & + & 2 & $\mathrm{~F}$ & $-\mathrm{D}$ & + \\
\hline Votic & 2 & + & $+\mathrm{D}$ & 1 & $\mathrm{~F}$ & $+1-$ & + \\
\hline Livonian & 2 & + & + & 1 & $F$ & - & + \\
\hline
\end{tabular}




\begin{tabular}{|c|c|c|c|c|c|c|c|}
\hline Saami & $P 1$ & $P 2$ & $P 3$ & P4 & P5 & P6 & $P 7$ \\
\hline Kildin Saami & 2 & + & + & 1 & $\mathrm{~F}$ & $-1+$ & + \\
\hline Skolt Saami & 2 & + & $+/-$ & 1 & $\mathrm{~F}$ & $-1+$ & + \\
\hline Pite Saami & 2 & - & - & 1 & $\mathrm{~F}$ & $-1+$ & + \\
\hline Volgaic/Permic & $P 1$ & $P 2$ & $P 3$ & P4 & P5 & P6 & $P 7$ \\
\hline Erzya & - & + & + & 0 & $\mathrm{~N}$ & $+/-$ & - \\
\hline Moksha & - & + & + & 0 & $\mathrm{~F}(\mathrm{~V})$ & $+1-$ & - \\
\hline Meadow Mari & - & $+/-$ & $+/-$ & 0 & $\mathrm{~V}$ & $+\mathrm{L}$ & - \\
\hline Hill Mari & - & $+/-$ & $+/-$ & 0 & $\mathrm{~N}(\mathrm{~F})$ & + & - \\
\hline Udmurt & - & + & + & 0 & $\mathrm{~F}(\mathrm{~V})$ & - & - \\
\hline Zyryan & $-\mathrm{D}$ & + & + & 0 & $\mathrm{~N}$ & - & - \\
\hline Permyak & - & + & + & 0 & $\mathrm{~V}$ & - & - \\
\hline Ugric & $P 1$ & $P 2$ & P3 & P4 & P5 & P6 & P7 \\
\hline Hungarian & 2 & + & + & 1 & $\mathrm{~F}$ & $+\mathrm{L}$ & - \\
\hline North Khanty & 2 & - & $+1-$ & 0 & $\mathrm{~F}(\mathrm{~V})$ & - & - \\
\hline East Khanty & $2>-$ & - & $+/-$ & 1 & $\mathrm{~V}(\mathrm{~N})$ & $+\mathrm{D}$ & - \\
\hline North Mansi & 2 & - & + & 0 & $\mathrm{~F}$ & - & - \\
\hline East Mansi & 2 & $+/-$ & + & 0 & $\mathrm{~F}$ & - & - \\
\hline Samoyedic & $P 1$ & $P 2$ & P3 & P4 & P5 & P6 & $P 7$ \\
\hline Nganasan & 2 & + & + & 0 & $\mathrm{~V}$ & $-1+$ & + \\
\hline Tundra Enets & 2 & + & + & 0 & $\mathrm{~N}$ & - & $-1+$ \\
\hline Forest Enets & 2 & + & + & 0 & $\mathrm{~N}$ & - & - \\
\hline Tundra Nenets & 2 & + & ++ & 0 & $\mathrm{~F}$ & - & - \\
\hline Forest Nenets & 2 & $+/-$ & ++ & 0 & $\mathrm{~F}$ & - & - \\
\hline North Selkup & 2 & - & $+1-$ & 0 & $\mathrm{~V}$ & $-1+$ & $-1+$ \\
\hline South Selkup & 2 & + & - & 0 & $\mathrm{~V}$ & - & $-\mathrm{D}$ \\
\hline Kamas & 2 & + & ++ & 0 & $\mathrm{~V}(\mathrm{~N})$ & $+\mathrm{L}$ & - \\
\hline
\end{tabular}

N1. Dual number in the nominal paradigm

Values: Exists $[+]$

Does not exist [-]

This feature concerns only nouns but not pronouns. The cases in which dual number appears in a possessive paradigm and expresses the number of possessors are not considered here. 


\section{N2. Multiple plural markers}

Values: Exist [+]

Do not exist [-]

In some languages, there are plural markers that cannot be treated as morphophonological variants. For instance, in most Finnic languages the nominative plural marker is $-t$ or $-d$ but the plural marker of the oblique cases is $-i$. In Meadow Mari, there are the plural markers -vlak, $-s ̌ a m \partial c ̌$ and $-l a$ (not counting the associative plural marker -mət). Such languages are marked with $[+]$. If the variation of the plural markers comes simply from morphophonologically triggered modifications, this feature has the value $[-]$.

\section{N3. Possessive markers \\ Values: Exist [+] \\ Do not exist [-]}

If the nominal paradigm includes possessive forms, this feature has the value [+]. If possession is expressed only by case marking on the dependent noun (e.g. genitive marking), this feature has the value [-].

\section{N4. Approximate number of cases}

The value of this feature is a number or an interval. In fact, the number of cases is an ambiguous feature, since this number depends crucially on a particular description. For example, some scholars have suggested considering the Meadow Mari locative cases as adverbs but not case forms (Karmazin 1935: 28-29). In many languages one can find forms that have only partial similarity with cases (see for example Kiefer 1987 on Hungarian, or Markus and Rozhanskiy 2014 on Votic and Ingrian), which increases the possible variation in the number of cases. Cases that exist only in the pronominal system of the language are not considered here.

\section{N5. Accusative case}

Values: Exists [+]

Only pronominal $[+/-]$

Does not exist $[-]$

The accusative case is a special case that marks the object of transitive predicates. The accusative is functionally opposed to the nominative - the case of the subject. Some Uralic languages do not have a morphological accusative and the object can be marked with different cases, the choice of which depends on various parameters. For such 
languages, this feature has the value [-]. In some languages (Finnish, Karelian, Ingrian, Votic, etc.), a special accusative case exists only in the pronominal system. The mark $[+/-]$ is used for such languages. In the Finnish tradition, the term accusative denotes rather the syntactic accusative of nouns, i.e. the case of the total object (which is in fact marked with the nominative or genitive). We understand the term accusative exclusively as a morphological case. The languages that have an unambiguous accusative have the mark $[+]$ even if under some conditions the direct object can be unmarked and coincides with the nominative form (e.g. in Mari).

\section{N6. Opposition of internal and external cases}

Values: Exists [+]

Only remnants exist [+/-]

Does not exist [-]

Most Finnic languages have a series of locative cases where the cases with the localization "in" are opposed to the series of cases with the localization "on". Such languages have the value [+].

\section{N7. Definiteness markers in nominal forms}

Values: Exist [+]

Do not exist [-]

Do not exist but the language has articles [a]

It is not typical for the Uralic languages to mark definiteness in the nominal paradigm. However, the Mordvin languages developed a special definite declension (they are marked with $[+]$ ), and Hungarian has definite and indefinite articles (marked with [a]).

Table 2. Nominal morphological features of Uralic languages

\begin{tabular}{|c|c|c|c|c|c|c|c|}
\hline Finnic & $N 1$ & N2 & N3 & N4 & N5 & N6 & N7 \\
\hline Finnish & - & + & + & 15 & $+/-$ & + & - \\
\hline Karelian & - & + & + & 14 & $+/-$ & + & - \\
\hline Veps & - & + & $-\mathrm{D}$ & 10 & - & + & - \\
\hline Ingrian & - & + & - & 13 & $+/-$ & + & - \\
\hline Estonian & - & + & - & 14-15 & - & + & - \\
\hline Votic & - & + & - & 11-13 & $+/-$ & + & - \\
\hline Livonian & - & + & - & $8-12$ & - & $-1+$ & - \\
\hline
\end{tabular}


22 Gerson Klumpp, Lidia Federica Mazzitelli, Fedor Rozhanskiy

\begin{tabular}{l|c|c|c|c|c|c|c}
\hline \multicolumn{1}{|c|}{ Saami } & $N 1$ & $N 2$ & $N 3$ & $N 4$ & $N 5$ & $N 6$ & $N 7$ \\
\hline Kildin Saami & - & - & + & 9 & + & - & - \\
\hline Skolt Saami & - & - & $+>-$ & 9 & + & - & - \\
\hline Pite Saami & - & - & $+>-$ & 9 & + & - & - \\
\hline \multicolumn{1}{c|}{ Volgaic/Permic } & $N 1$ & $N 2$ & $N 3$ & $N 4$ & $N 5$ & $N 6$ & $N 7$ \\
\hline Erzya & - & - & + & 11 & - & - & + \\
\hline Moksha & - & - & + & 12 & - & - & + \\
\hline Meadow Mari & - & + & + & $7-9$ & + & - & - \\
\hline Hill Mari & - & - & + & $7-10$ & + & - & - \\
\hline Udmurt & - & - & + & 15 & + & $+/-$ & - \\
\hline Zyryan & - & - & + & 16 & + & $+/-$ & - \\
\hline Permyak & - & - & + & 17 & + & $+/-$ & - \\
\hline & $N 1$ & $N 2$ & $N 3$ & $N 4$ & $N 5$ & $N 6$ & $N 7$ \\
\hline Hungarian & - & + & + & $16-28$ & + & + & $\mathrm{a}$ \\
\hline North Khanty & + & - & + & 3 & $+/-$ & - & - \\
\hline East Khanty & + & - & + & $9-11$ & $+/-$ & - & - \\
\hline North Mansi & + & - & + & $6-8$ & $+/-$ & - & - \\
\hline East Mansi & + & - & + & 8 & + & - & - \\
\hline Samoyedic & $N 1$ & $N 2$ & $N 3$ & $N 4$ & $N 5$ & $N 6$ & $N 7$ \\
\hline Nganasan & + & - & + & 7 & + & - & - \\
\hline Tundra Enets & + & - & + & 6 & - & - & - \\
\hline Forest Enets & + & - & + & 6 & - & - & - \\
\hline Tundra Nenets & + & + & + & 7 & + & - & - \\
\hline Forest Nenets & + & + & + & 7 & + & - & - \\
\hline North Selkup & + & + & + & $9-13$ & + & - & - \\
\hline Kauth Selkup & + & - & + & $13-14$ & + & - & - \\
\hline
\end{tabular}

V1. Dual number in the verbal paradigm

Values: Exists [+]

Does not exist [-]

In most cases this feature correlates with the feature N1 Dual number in the nominal paradigm. However, in Pite Saami and in Kamas the dual number exists only in the verbal, but not in the nominal paradigm. 


\section{V2. Objective conjugation (object agreement)}

Values: Exists [+]

Does not exist $[-]$

This feature has the value [+] if there is a separate series of verbal forms where the type of object is morphologically marked.

\section{V3. Future tense in the verbal paradigm}

Values: Exists [+]

Does not exist $[-]$

Many Uralic languages do not have a special verbal form for expressing the future tense. The present-future verbal form obtains either present or future interpretation due to various factors (including the object-case marking, temporal adverbs, semantic context, etc.). Such languages get the mark [-] even if they have a special verbal lexeme with a future meaning (as in some Finnic languages).

\section{V4. Analytic perfect and pluperfect}

Values: Exist [ + ]

Similar forms exist but usually they are not considered as perfect and pluperfect [+/-]

Do not exist [-]

The perfect and pluperfect are analytic verbal forms built with the form of the verb 'to be' (present for perfect and past for pluperfect) which bears grammatical characteristics and a form of the lexical verb (usually non-finite). Such forms express actions in the past, often with the semantic components of result (perfect), remote past (pluperfect) and others. The languages with such forms have the mark [+], while the languages that have a form with the perfect or pluperfect meaning, but built in a different way, have the mark [-]. The Mari languages, where similar forms exist but are not considered as perfect and pluperfect, have the mark $[+/-]$.

\section{V5. Opposition of two synthetic past tenses}

Values: Exists $[+]$

Does not exist [-]

Uralic languages that have more than one past tense with special verbal markers have the mark [+]. If only one synthetic past tense exists in a language, it has the mark [-]. 
V6. Contrast of personal and impersonal forms

Values: Exists $[+]$

Does not exist [-]

Some Finnic and Saami languages have special verbal forms that express actions without an explicit subject. Such languages have the mark [+]. If there are not such forms in a language or they coincide with some personal forms, the language has the mark [-].

\section{V7. Synthetic jussive and hortative}

Values: Both the jussive and hortative exist [ $\mathrm{J} \mathrm{H}]$

Only the jussive exists [J]

Neither the jussive nor hortative exist [-]

All Uralic languages have imperative forms of the 2 nd person. However, only some of the languages have 3rd person imperative forms (jussive) or 1st person imperative forms (hortative). In this feature, only the morphological forms with special markers are considered. If a language has only analytical forms of the type Let him/me do it!, but no morphological jussive or hortative forms, it is marked with [-].

Table 3. Verbal morphological features of the Uralic languages

\begin{tabular}{|c|c|c|c|c|c|c|c|}
\hline Finnic & $V 1$ & $V 2$ & $V 3$ & $V 4$ & V5 & V6 & $V 7$ \\
\hline Finnish & - & - & - & + & - & + & $\mathrm{J}, \mathrm{H}$ \\
\hline Karelian & - & - & - & + & - & - & $\mathrm{J}$ \\
\hline Veps & - & - & - & + & - & $+\mathrm{D}$ & $\mathrm{J}, \mathrm{H}$ \\
\hline Ingrian & - & - & - & + & - & + & $-\mathrm{D}$ \\
\hline Estonian & - & - & - & + & - & + & $\mathrm{J}, \mathrm{H}$ \\
\hline Votic & - & - & - & + & - & - & $\mathrm{J}$ \\
\hline Livonian & - & - & - & + & - & - & $\mathrm{J}$ \\
\hline Saami & $V 1$ & $V 2$ & $V 3$ & V4 & V5 & V6 & $V 7$ \\
\hline Kildin Saami & - & - & - & + & - & + & - \\
\hline Skolt Saami & - & - & - & + & - & + & $\mathrm{J} \mathrm{H}$ \\
\hline Pite & + & - & - & + & - & - & - \\
\hline
\end{tabular}




\begin{tabular}{l|c|c|c|c|c|c|c}
\hline \multicolumn{1}{c|}{ Volgaic/Permic } & $V 1$ & $V 2$ & $V 3$ & $V 4$ & $V 5$ & $V 6$ & $V 7$ \\
\hline Erzya & - & + & - & - & + & - & $\mathrm{J}(\mathrm{H})$ \\
\hline Moksha & - & + & - & - & - & - & $\mathrm{J}(\mathrm{H})$ \\
\hline Meadow Mari & - & - & - & +- & + & - & $\mathrm{J}$ \\
\hline Hill Mari & - & - & - & +- & + & - & $\mathrm{J}$ \\
\hline Udmurt & - & - & + & - & + & - & - \\
\hline Zyryan & - & - & + & - & + & - & - \\
\hline Permyak & - & - & + & - & + & - & - \\
\hline & $V 1$ & $V 2$ & $V 3$ & $V 4$ & $V 5$ & $V 6$ & $V 7$ \\
\hline Hungarian & - & + & + & - & - & - & $\mathrm{J} \mathrm{H}$ \\
\hline North Khanty & + & + & - & - & - & - & - \\
\hline East Khanty & + & + & - & - & $-\mathrm{D}$ & - & - \\
\hline North Mansi & + & + & - & - & - & - & - \\
\hline East Mansi & + & + & - & - & - & - & $\mathrm{J} \mathrm{H}$ \\
\hline \multicolumn{1}{|c|}{ Samoyedic } & $V 1$ & $V 2$ & $V 3$ & $V 4$ & $V 5$ & $V 6$ & V7 \\
\hline Nganasan & + & + & + & - & - & - & $\mathrm{J} \mathrm{H}$ \\
\hline Tundra Enets & + & + & + & - & + & - & $\mathrm{J} \mathrm{H}$ \\
\hline Forest Enets & + & + & + & - & + & - & $\mathrm{J} \mathrm{H}$ \\
\hline Tundra Nenets & + & + & + & - & - & - & $\mathrm{J} \mathrm{H}$ \\
\hline Forest Nenets & + & + & + & - & - & - & $\mathrm{J} \mathrm{H}$ \\
\hline North Selkup & + & + & - & - & + & - & $\mathrm{J} \mathrm{H}$ \\
\hline South Selkup & + & + & + & - & + & - & $\mathrm{J} \mathrm{H}$ \\
\hline Kamas & + & + & + & - & - & - & $\mathrm{J} \mathrm{H}$ \\
\hline
\end{tabular}

S1. Basic word order

Values: SVO

\section{SOV}

The Uralic languages have either SOV or SVO basic word order. Many Uralic languages do not have a strict word order and the chosen value for such languages is debatable.

S2. Pro-drop

Values: Pro-drop is the main strategy $[+]$

Pro-drop is not the main strategy [-]

For many Uralic languages it is typical to drop the pronominal subject because the person and number of the subject are understandable 
from the verbal form. Most of them drop the pronominal subject as a main strategy (value $[+]$ ), but in some languages the use of a pronominal subject dominates (value $[-]$ ).

\section{S3. Copula is obligatory}

Values: Usually yes [+]

Depends on the person $[-/+]$

Usually not [-]

Many Uralic languages allow dropping the copula in sentences like My son [is] a fisherman. Such languages have the value [-]. If the dropping of the copula is rare and is interpreted rather as ellipsis, the language has the value $[+]$. Some languages allow the dropping of the copula only in constructions with the 3 rd person subject (value $[-/+]$ ). In verbal tenses other than the present, the copula is usually obligatory, so we do not consider such constructions here.

\section{S4. Agreement in the adjective phrase}

Values: Usually yes [+]

$$
\text { Usually no [-] }
$$

If an adjective preceding a noun agrees with this noun in number and case, this feature has the value $[+]$. If there is no such agreement, the language has the value $[-]$.

Table 4. Syntactic features of the Uralic languages

\begin{tabular}{|c|c|c|c|c|}
\hline Finnic & $S 1$ & $S 2$ & S3 & $S 4$ \\
\hline Finnish & SVO & + & + & + \\
\hline Karelian & SVO & + & + & + \\
\hline Veps & SVO & + & - & + \\
\hline Ingrian & SVO & - & - & + \\
\hline Estonian & SVO & + & + & + \\
\hline Votic & SVO & - & - & + \\
\hline Livonian & SVO & + & + & + \\
\hline Saami & $S 1$ & $S 2$ & $S 3$ & $S 4$ \\
\hline Kildin Saami & SVO & + & + & - \\
\hline Skolt Saami & SOV/SVO & + & + & - \\
\hline Pite & SVO & + & + & - \\
\hline
\end{tabular}




\begin{tabular}{|c|c|c|c|c|}
\hline Volgaic/Permic & S1 & $S 2$ & S3 & $S 4$ \\
\hline Erzya & SVO & + & - & - \\
\hline Moksha & SVO & + & - & - \\
\hline Meadow Mari & SOV & + & $-1+$ & - \\
\hline Hill Mari & SOV & + & $-1+$ & - \\
\hline Udmurt & SOV & + & - & - \\
\hline Zyryan & SVO & + & - & - \\
\hline Permyak & SVO & + & - & - \\
\hline Ugric & S1 & $S 2$ & S3 & $S 4$ \\
\hline Hungarian & SOV & + & $-1+$ & - \\
\hline North Khanty & $\mathrm{SOV}$ & + & $+\mathrm{D}$ & - \\
\hline East Khanty & SOV & + & - & - \\
\hline North Mansi & SOV & + & - & - \\
\hline East Mansi & SOV & + & $-1+$ & - \\
\hline Samoyedic & S1 & $S 2$ & $S 3$ & $S 4$ \\
\hline Nganasan & SOV & + & - & + \\
\hline Tundra Enets & SOV & + & - & - \\
\hline Forest Enets & SOV & + & - & - \\
\hline Tundra Nenets & SOV & + & - & - \\
\hline Forest Nenets & $\mathrm{SOV}$ & + & - & - \\
\hline North Selkup & SOV & + & - & - \\
\hline South Selkup & $\mathrm{SOV}$ & + & $-1+$ & - \\
\hline Kamas & $\mathrm{SOV}$ & + & $-1+$ & - \\
\hline
\end{tabular}

\section{Acknowledgments}

We are especially grateful to Ante Aikio, Nikolett F. Gulyás, Valentin Gusev, Timothy Feist, Olesya Khanina, Martin Joachim Kümmel, Mehmet Muslimov, Juho Pystynen, Alexandra Rodionova, Joshua Wilbur, Andrey Shluinsky, Jussi Ylikoski, Daria Zhornik and other colleagues for the discussion on the data. All possible flaws in the interpretation of data are the responsibility of the authors of this chapter only. We are also grateful to Miina Norvik, Karl Pajusalu, Triin Todesk, and Marili Tomingas for the Estonian abstracts. 


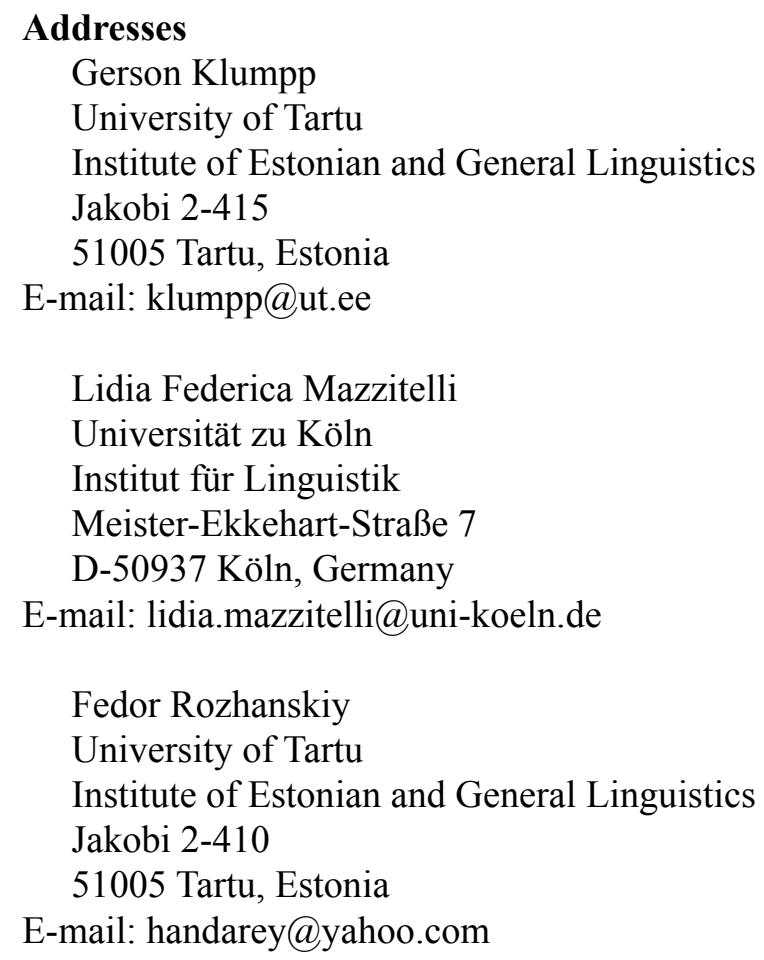

\section{References}

Ariste, Paul (1948) Vadja keele grammatika. Tartu: Teaduslik kirjandus.

Ariste, Paul (1968) A grammar of the Votic language. (Indiana University Publications, Uralic and Altaic Series, 68.) Bloomington: Indiana University Press.

Bubrix, Dmitrij V. (1949) Grammatika literaturnogo komi jazyka. Leningrad: Izdatel'stvo Leningradskogo universiteta.

De Groot, Casper, ed. (2017) Uralic Essive and the expression of impermanent state. (Typological Studies in Language, 119.) Amsterdam and Philadelphia: John Benjamins.

Dryer, Matthew S. and Martin Haspelmath, eds. (2013) The world atlas of language structures online. Leipzig: Max Planck Institute for Evolutionary Anthropology. Available online at $<$ http://wals.info $>$. Accessed on 25.07.2018.

Himmelmann, Nikolaus P. (2006) "Language documentation: what is it and what is it good for?”. In Jost Gippert, Nikolaus P. Himmelmann, and Ulrike Mosel, eds. Essentials of language documentation, 1-30. Berlin and New York: Mouton de Gruyter.

Karmazin, Gurij G. (1935) Padeži v marijskom jazyke. Joškar-Ola: Margosizdat. 
Kiefer, Ferenc (1987) “The cases of Hungarian nouns". Acta Linguistica Hungarica 37, 93-101.

Komi jazyk 1998 = Fedjuneva, Galina V., ed. Komi jazyk: énciklopedija. Moskva: DiK. Kovedjaeva, Evgenija I. (1966) "Marijskij jazyk". In Vasilij I. Lytkin, and Klara E. Majtinskaja, eds. Jazyki narodov SSSR. Vol. 3: Finno-ugorskie i samodijskie jazyki, 221-240. Moskva and Leningrad: Nauka.

Laanest, Arvo (1982) Einführung in die ostseefinnischen Sprachen. Hamburg: Buske. Lauerma, Petri (1993) Vatjan vokaalisointu. Helsinki: Suomalais-Ugrilainen Seura.

Lytkin, Vasilij I. (1966) "Komi-zyrjanskij jazyk". In Vasilij I. Lytkin and Klara E. Majtinskaja, eds. Jazyki narodov SSSR. Vol. 3: Finno-ugorskie jazyki i samodijskie jazyki, 281-299. Moskva, and Leningrad: Nauka.

Markus, Elena, and Fedor Rozhanskiy (2014) "Comitative and terminative in Votic and Lower Luga Ingrian”. Linguistica Uralica 50:4, 241-257.

Markus, Elena, and Fedor Rožanskiy (2017) Sovremennyj vodskij jazyk: teksty $i$ grammatičeskij očerk. St. Petersburg: Nestor-Istorija.

Miestamo, Matti, Anne Tamm, and Beáta Wagner-Nagy (2015) Negation in Uralic languages. (Typological Studies in Language, 108.) Amsterdam and Philadelphia: John Benjamins.

Nikolaeva, Irina (1999) Ostyak. München: Lincom Europa.

Nikolaeva, Irina (2014) A grammar of Tundra Nenets. (Mouton Grammar Library, 65.) Berlin: Mouton de Gruyter.

Ristinen, Elaine K. (1960) An East Cheremis Phonology. (Indiana University Publications, Uralic and Altaic Series, 1.) Bloomington: Indiana University Press.

Rozhanskiy, Fedor (2013) "Morphophonological nature of Mari accentuation as viewed from the Uralic perspective". Linguistica Uralica 49:3, 184-207.

Siegl, Florian (2013) Materials on Forest Enets, an indigenous language of Northern Siberia. (Mémoires de la Société Finno-Ougrienne, 267.) Helsinki: SuomalaisUgrilainen Seura.

Sjögren, Johan A. (1861) Livische Grammatik nebst Sprachproben. St. Petersburg: Commissionare der Kaiserlichen Akademie der Wissenschaften.

Wilbur, Joshua (2015) A grammar of Pite Saami. (Studies in Diversity Linguistics, 5.) Berlin: Language Science Press.

Winkler, Eberhard (2001) Udmurt. München: Lincom Europa.

Аннотация. Типология уральских языков: современное состояние и новые перспективы. Во вступительной статье к данному тому обсуждается история и современное состояние уралистики. Основное внимание уделяется эволюции грамматических описаний от первых грамматик уральских языков до настоящего времени. В Разделе 2 показано, что уральским языкам посвящено немало лингвистических трудов и, в частности, грамматических описаний. Однако существующие грамматики в большинстве своем обнаруживают такие недостатки, как слабая 
сопоставимость (в том числе терминологическая), недоступность для широкого круга лингвистов (прежде всего, из-за языка грамматики) и отсутствие типологической ориентированности. Становится очевидной насущная потребность в более тесном взаимодействии типологии и уралистики. В Разделе 3 предлагается обзор статей, вошедших в данный том. Эти статьи обсуждают различные явления в уральских языках, но их объединяет типологически ориентированный подход, акцент на используемых данных и терминологическая последовательность. В Разделе 4 дается краткий обзор типологических признаков, релевантных для интрагенетической типологии уральской семьи.

Ключевые слова: уралистика, типологические признаки, грамматическое описание

Kokkuvõte. Uurali keelte tüpoloogia: nüüdisaegsed vaated ja uued vaatenurgad. Sissejuhatus. Väljaande sissejuhatuses käsitleme uralistika ajalugu ja praegusi arenguid, keskendudes eelkõige grammatikakirjutuse arengule alates esimestest uurali grammatikatest kuni tänapäevani ja võttes kokku tüpoloogilisest vaatepunktist mõned kõige huvitavamad nähtused uurali keeltes. Sissejuhatuse teises peatükis näitame, et kuigi uurali keeltest leidub märkimisväärne arv keeleteaduslikke uurimusi ja suur hulk deskriptiivseid grammatikaid, puudub avaldatud grammatikates sageli võrreldavuse tasand (väljaannetes kasutatakse sama nähtuse kirjeldamiseks erinevaid termineid), rahvusvaheline mõõde ning tüpoloogiline informatsioon. Seetõttu toetame tugevama koostöö arendamist tüpoloogia ja uurali uuringute vahel. Kolmandas peatükis esitleme käesoleva ESUKA eriväljaande artikleid, mis on valik tüpoloogilise informatsiooniga, andmepõhiseid ja terminoloogiliselt järjepidevaid uurimusi uurali keeltest. Viimases, neljandas peatükis anname lühiülevaate mõnedest vastavatest tüpoloogilistest omadustest uurali keeltes.

Märksõnad: uralistika, tüpoloogilised jooned, grammatikakirjutus 